\title{
The relative importance of colour, taste and smell in the protection of an aposematic insect Coccinella septempunctata
}

\author{
NICOLA M. MARPLES*, WILLEM VAN VEELEN \& PAUL M. BRAKEFIELD \\ Section of Evolutionary Biology, Institute of Evolutionary and Ecological Sciences, \\ University of Leiden, Schelpenkade 14a, NL-2313 ZT Leiden, The Netherlands
}

(Received 11 June 1993; initial acceptance 11 August 1993; final acceptance 1 November 1993; MS. number: 4417)

\begin{abstract}
The response of a bird predator (Japanese quail, Coturnix coturnix japonicus) to the potential cues present in the multiple-component defence of an aposematic insect (seven-spot ladybird, Coccinella septempunctata) was investigated. Ladybirds were presented to captive quail either whole, or in treatments in which the ladybird's colour pattern, smell or taste were added to a palatable beetle, either singly or in paired combinations. Colour pattern was the most effective single deterrent, but the interaction between colour and taste was also important. The birds could detect the insect's smell, but rarely used it as a cue to toxicity. No element, either alone or in paired combination, was sufficient to maintain avoidance at a level comparable to the whole insect. The results are discussed with respect to aposematic function and avian foraging behaviour.
\end{abstract}

When an insect is brightly coloured and contains a toxin it is said to exhibit aposematic coloration (Brower 1984). Its predators learn to associate the colour pattern with the effects of the toxin and so avoid the insect. In addition to the colour pattern (and occasionally instead of it) cues may take the form of sound, smell or taste (Pasteur 1982; Brower 1984). A few studies have demonstrated that taste and appearance can be important to how birds learn to avoid toxic prey (Wilcoxen et al. 1971; Gillette et al. 1980). The roles of the different cues appear to vary with the species of bird involved, and whether the prey is solid or liquid; domestic chicks, Gallus gallus domesticas, respond more to the taste of water than to its colour unless they are forced to view the water repeatedly before drinking (Gillette et al. 1980), while quail pay more attention to visual cues than to taste when presented with coloured or sour water (Wilcoxen et al. 1971). Chicks use colour as a cue preferentially when learning about solid food (Gillette et al. 1980).

The present experiment seeks to extend such work to investigate the relative effectiveness of cues present in a naturally occurring defence system, that of the seven-spot ladybird, Coccinella septempunctata. The cues examined were colour

*Present address: School of Biological Sciences, University of Sussex, Brighton BN1 9QG, U.K. pattern, smell and taste, since these are features known to be shared by the seven-spot ladybird and its mimics (Brakefield 1985).

The seven-spot ladybird is toxic to blue tit, Parus caeruleus, nestlings (Marples et al. 1989) and contains two alkaloids, coccinelline and its free base precoccinelline (Pasteels et al. 1973), which taste bitter. The alkaloid is distributed throughout the body of the adult seven-spot ladybird, but is more concentrated in the reflex blood that exudes from the tibia/femur joint of the legs, when the ladybird is attacked (Kay et al. 1969; Holloway et al. 1991). Reflex bleeding involves the exudation of fluid through pores in the knee joints of all six legs which serves to transport defensive compounds to the surface (Cuenot 1896; Hodek 1973; Holloway et al. 1991).

The reflex blood has a strong smell of pyrazines (Rothschild \& Moore 1987). It was not known whether quail could smell this substance, but chicks have been shown to do so (Guilford et al. 1987), and evidence has been presented for good olfactory function in a wide range of birds (for example see Tucker 1965). The wide distribution of pyrazines and their proposed role as a general alerting signal (Rothschild \& Moore 1987) also supports the argument that they are detectable by birds other than chickens. Discrimination by smell is known in a range of bird species; for instance Clark \& Mason (1987) showed that starlings, 
Sturnus vulgaris, choose their nesting materials on the basis of odour.

As an insectivorous bird approaches and attacks a ladybird beetle, it presumably experiences the cues in sequence, the aposematic colouring first, then the smell and then the taste. The colour pattern is readily seen because both twospot and seven-spot ladybirds rest conspicuously as adults. As soon as the beetle is attacked it reflex bleeds, greatly increasing the smell and exposing the bitter tasting fluid for quick detection as the beetle is mandibulated (Majerus \& Kearns 1989).

\section{METHODS}

\section{The Seven-spot Ladybirds}

The seven-spot ladybirds were collected from a single hibernation site in England and another in The Netherlands, and maintained in the laboratory on a diet of pea aphids, Acyrthosiphon pisum. The ladybirds were kept at a temperature of $20^{\circ} \mathrm{C}$, a relative humidity of $70-80 \%$ and a light:dark regime of $16: 8 \mathrm{~h}$.

Each fully active seven-spot ladybird was presented to the birds only once, although some of those providing reflex blood were bled two or three times. In these cases there was always at least a week between the bleedings to let them replenish their reflex blood and coccinelline (Holloway et al. 1991).

Reflex blood from 10 individual ladybirds from each hibernation site was tested for uniformity of alkaloid content. The reflex blood was collected and its alkaloid content measured by gas chromatography as described by Holloway et al. (1991). No significant differences between hibernation sites were found (Mann-Whitney $U$-test: $U=94 \cdot 0$, $N=10,10, P=0.427)$.

\section{The Japanese Quail}

The birds used were adult laboratory-bred Japanese quail, Coturnix coturnix japonicus. The birds were maintained on a diet of chicken pellets and mealworms supplemented with a mixture of minerals. They were held in separate cages measuring $1 \times 0.5 \times 1 \mathrm{~m}$ and offered a sandbath every 3 or 4 days. The room was large and well ventilated, and was maintained at $21^{\circ} \mathrm{C}\left( \pm 1^{\circ} \mathrm{C}\right)$ with a light:dark regime of 16:8 h.
The birds came from two stocks, one bred to accept unfamiliar prey quickly and one with birds that did so slowly (Marples \& Brakefield, in press). Most of them (49) were of the second and some (12) of the third generation after selection began. All the birds had encountered and learned to eat 'control' beetles Alphitobius diaperinus (a dark brown palatable beetle, comparable in size to a ladybird), and mealworms, Tenebrio molitor, and had learned to avoid seven-spot ladybirds over at least three encounters about 2 months before the experiment began. Forty-nine of the birds had also experienced both typical and melanic forms of the two-spot ladybird, Adalia bipunctata, which is mildly distasteful but not toxic (Marples et al. 1989), and learned to eat or avoid them. Birds from each breeding stock, sex and two-spot ladybird experience were distributed as evenly as possible across all treatments to minimize the effects of these parameters on the results.

The birds were offered a seven-spot ladybird 2 weeks before the start of the experiment to standardize the time between the last encounter with a seven-spot ladybird and the start of the experiment. In previous experiments (Marples 1990), 2 weeks was sufficient time to allow the birds' aversion to seven-spot ladybirds to wane, ensuring that they resampled the ladybirds when the experiment began. The day before the experiment each bird received a piece of bread dough to acquaint them with the taste, as birds in group 4 would receive this as part of their treatment (see below).

\section{Experimental Procedure}

The birds were divided into three groups of 15 and one of 16 birds (smell treatment). Each group was given treatments in two sessions of 11 days each. The first session was designed to investigate the effects of each part of the seven-spot ladybird defence system, and the second session demonstrated the change in response when a new defence cue is added. This arrangement gave two beneficial effects. More birds could be tested on each treatment than would have been possible if the second session treatments had been given to four new groups of birds, since bird numbers were limited. It also allowed the changes in behaviour arising from the added cue to be seen more clearly, as no other factors (such as necessarily occur at the start of an experiment) occurred at that point. eac

rec

Th

the

lad

col

blc

ser

wa

tas

is

thi

vo

in

su

lo:

un 
Table I. The ladybird defence cues presented in the two sessions of the experiment

\begin{tabular}{cll}
\hline Group of birds & \multicolumn{1}{c}{ Session 1 } & \multicolumn{1}{c}{ Session2 } \\
\hline 1 & Colour, taste, smell, toxic & Colour, taste, smell, less toxic \\
2 & Taste, smell, non-toxic & Taste, smell, colour, non-toxic \\
3 & Smell, non-toxic & Smell, colour, non-toxic \\
4 & Colour, non-toxic & Colour, smell, non-toxic \\
\hline
\end{tabular}

Table I summarizes the treatment presented to each group of birds. In the first session, group 1 received a whole untreated seven-spot ladybird. Thus, these birds were exposed to prey that has the appearance, smell and taste of a seven-spot ladybird, and was also toxic. Group 2 received a control beetle with seven-spot ladybird reflex blood on it, so it smelled and tasted like a seven-spot ladybird but did not look like one and was not toxic. It was not possible to present the taste of the seven-spot ladybird alone, as the taste is present in the reflex blood, which also carries the smell. The reflex fluid was diluted in twice its volume of water and control beetles were dipped in this mixture so that it coated their dorsal surface. The drying of the mixture and the gradual loss of any volatile elements may have led to an underestimation of the importance of the taste and smell treatment (referred to as 'taste treatment'). Group 3 received a (non-toxic) control beetle associated only with the smell of a seven-spot ladybird. This was achieved by presenting the beetle in a petri dish (diameter $5.5 \mathrm{~cm}$ ) with small holes in the bottom and a crushed ladybird underneath it. The bottom of the petri dish had been painted white to prevent the bird from seeing the crushed seven-spot ladybird. All treatments were presented in this type of petri dish. Group 4 received a control beetle on which two elytra of a seven-spot ladybird had been attached with woodglue and dough. Dough was used as it is a fully edible substance that can easily be moulded to fill the space between the ladybird elytra and those of the slightly smaller control beetle. All the birds ate dough readily. The ladybird elytra were dipped in chloroform to remove any possible smell and taste, and dried before they were attached. A preliminary experiment showed no significant influence of glue or chloroform on the eating behaviour of the quail. This treatment resulted in a fully palatable beetle which looked like a seven-spot ladybird in colour pattern, size and shape.
After the last bird had finished session 1, there was a week's gap before session 2 was started. During the second session, the first group, which had received a whole seven-spot ladybird in session 1, now received seven-spot ladybirds that had been bled to reduce their alkaloid content, and remove their ability to reflex bleed in response to attack. These beetles were therefore less well defended than the whole unbled ladybirds. Bleeding was continued until the ladybird ceased to produce reflex blood, and was carried out just before the experiment. The birds in group 2 had colour added to their taste treatment, and the birds from groups 3 and 4 now received colour and smell together (see Table I).

A mealworm was presented with each beetle to ensure that the bird approached the petri dish and saw the beetle. The trial continued until the bird walked away from the beetle for the second time. This reduced the chance that a bird would handle a ladybird because it had nothing else to do. The times when the bird ate the mealworm and the time from then until the bird ate the beetle were recorded. The time at which it chewed or pecked at the beetle for the first time and whether it performed a headshake or beakwipe were also noted. A 'peck' was scored when the beetle had no clear damage and a 'chew' when the beetle had been damaged. Uneaten but pecked or chewed beetles were kept in a petri dish with food for 2 days to record how many died of their injuries.

\section{RESULTS}

Since the results from individual quail are so variable from day to day only the pooled results from birds on the same treatment are presented. Tables II and III include the numbers of birds showing each behaviour pattern; these data demonstrate that the pooled results were not due to aberrant behaviour of individual birds. 

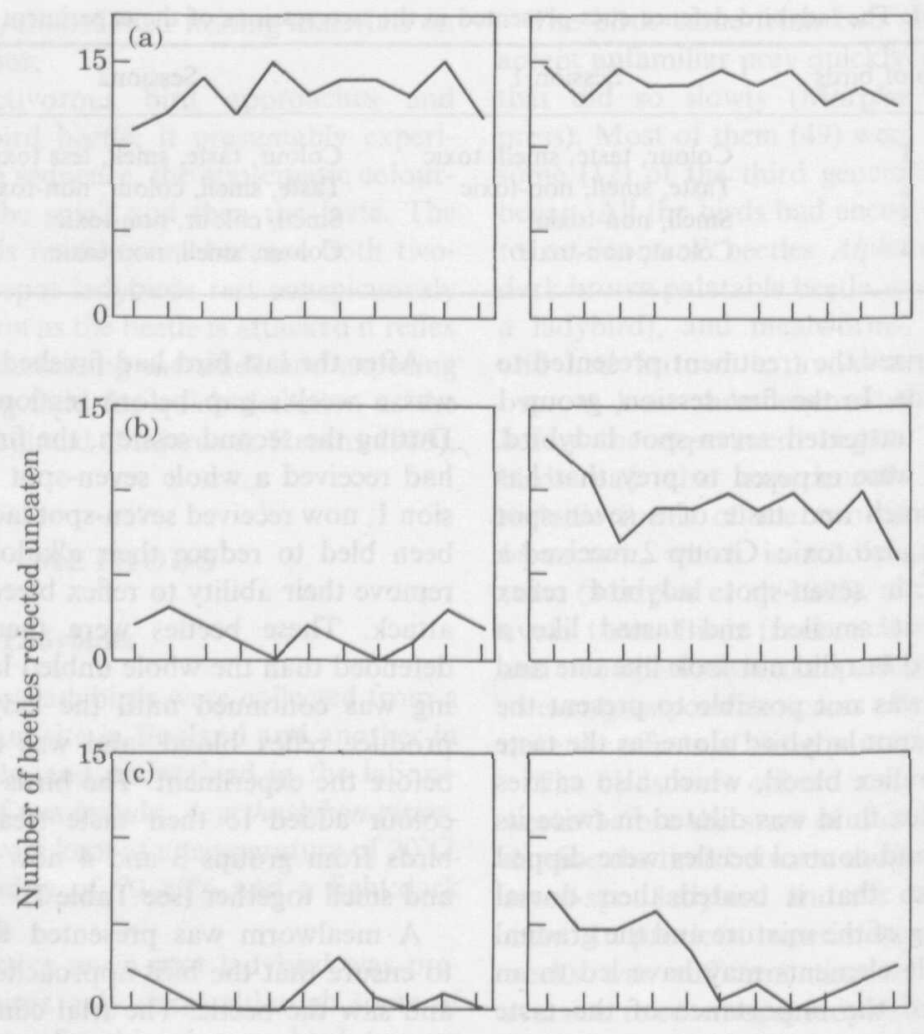

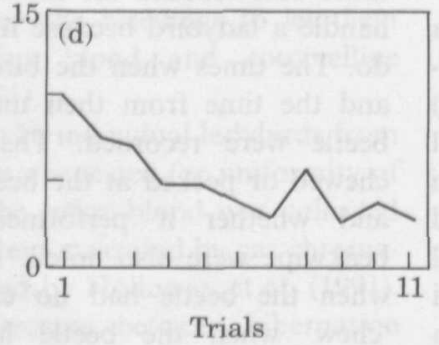

Session 1

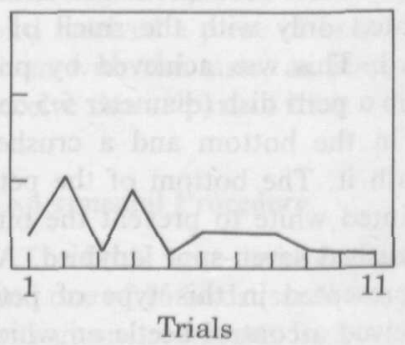

Session 2

Figure 1. The numbers of beetles rejected in each trial by quail. (a) Unbled seven-spot ladybirds offered for 11 trials, then seven-spot ladybirds that had been reflex-bled for the remaining trials. (b) Edible beetles carrying the taste of seven-spot ladybird in the form of reflex blood offered for 11 trials, then carrying both the taste and the colour pattern for the remaining trials. (c) Edible beetles in the presence of the smell of seven-spot ladybird offered for 11 trials, then both the smell and the colour pattern for the remaining trials. (d) Edible beetles with the colour pattern of seven-spot ladybird offered for 11 trials, then carrying both the colour pattern and the smell for the remaining trials.

\section{Whole and Bled Ladybirds}

The birds avoided the whole seven-spot ladybirds, and maintained a high level of rejection throughout both sessions (Fig. 1a). Even after reflex bleeding the chemical defence was enough to sustain rejection. Indeed, the survival data (Fig. 2) show that in comparison with unbled beetles, significantly fewer bled seven-spot ladybirds were touched $\left(\chi^{2}=6 \cdot 3, d f=1, P<0 \cdot 05\right)$ or eaten $\left(\chi^{2}=4 \cdot 3\right.$, $d f=1, \quad P<0.05)$ than unbled ones. Fewer bled $\operatorname{sev}$

the

the

pre

$(50$

an

lad

$(72$

an

bu

or

$\mathrm{m}$

dis

$\mathrm{m}$

su

$\mathbf{T l}$

ta

no

$N$

1

th

ta

si

ca

fir

$\chi$

$P$ 

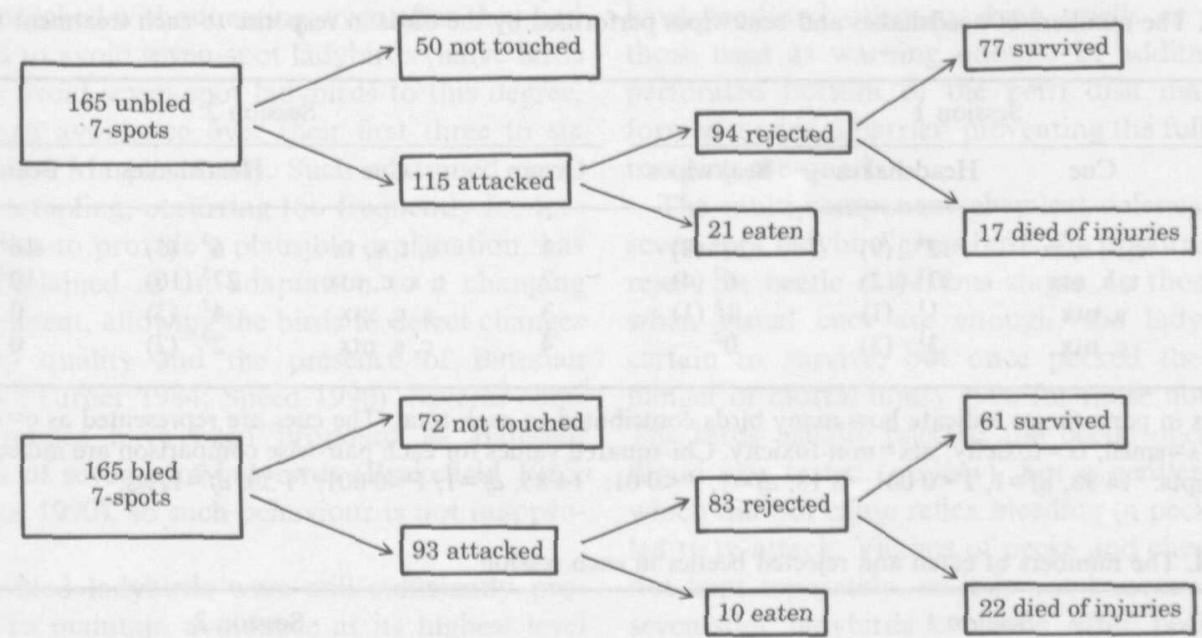

Figure 2. The fate of unbled and bled seven-spot ladybirds when presented to the birds.

seven-spot ladybirds survived an attack, although the difference was not significant.

Overall survival was high (Fig. 2); $77 \%$ (127) of the 165 unbled seven-spot ladybirds that were presented survived an encounter with a quail; $30 \%$ (50) were rejected on sight and $47 \%$ (77) survived an actual attack. Of the 165 bled seven-spot ladybirds, $81 \%$ (133) survived the encounter, $44 \%$ (72) were rejected on sight and $37 \%(61)$ survived an attack.

Of the 94 unbled seven-spot ladybirds attacked but not eaten, 29 were rejected after a chew (with or without additional pecks) and 65 after one or more pecks. As only 17 of these subsequently died, it is clear that even the more extensive mandibulation involved in a chew can be survived.

\section{The Taste}

The difference between the treatments smell and taste when presented separately (Fig. 1b, c) was not significant (Mann-Whitney $U$-test, $W=153.5$, $N=11,11, P=0 \cdot 07$ ), although in seven out of the 11 trials more birds rejected the beetle with taste than with smell. The addition of colour to the taste (Fig. 1b) and smell treatments (Fig. 1c) significantly raised the level of avoidance in each case (chi-squared test between session 1 and the first five points of session 2 ; taste $\rightarrow$ taste + colour: $\chi^{2}=78 \cdot 3$, smell $\rightarrow$ smell + colour: $\chi^{2}=40 \cdot 2, d f=1$, $P<0.001$ in each case). The graphs, and chi- squared values above, suggest that the effect was greater in birds given taste with colour than those given smell with colour. Avoidance of taste and colour was initially as high as the avoidance caused when whole seven-spot ladybirds were presented (Fisher's exact test with Yate's correction, $\left.\chi^{2}=0 \cdot 00, d f=1, \quad P=1 \cdot 00\right)$. Figure $1 \mathrm{~b}, \mathrm{c}$ suggests that the avoidance level was not maintained, although the decrease is significant only in the smell and colour treatment (Spearman rank correlation $\left.r_{\mathrm{S}}=-0.72, N=11, P<0.05\right)$. More headshakes and beakwipes were observed in the presence of the taste than in its absence (Table II).

\section{The Smell}

Smell on its own produced very little rejection (Fig. 1c), and the addition of smell to the colour pattern led to no apparent change in the rate of decline in avoidance (see Fig. 1d; Spearman rank correlation over both sessions: $r_{\mathrm{S}}=-0.862$, $N=22, P<0 \cdot 01$ ).

The data for the numbers of beetles eaten (Table III) indicate that the smell of a seven-spot ladybird on its own had a small but significant effect. When control beetles were presented to the birds without smell, all but one out of 110 were eaten. When the seven-spot ladybird smell was present, that number rose to eight out of 165 . This difference is on the margin of significance, tested with a $\log$ likelihood test $(G=3.832, P=0.0503)$. 
Table II. The numbers of headshakes and beakwipes performed by the birds in response to each treatment in each session

\begin{tabular}{|c|c|c|c|c|c|c|c|}
\hline \multicolumn{4}{|c|}{ Session 1} & \multicolumn{4}{|c|}{ Session 2} \\
\hline Group & Cue & Headshakes & Beakwipes & Group & Cue & Headshakes & Beakwipes \\
\hline 1 & $\mathrm{c}, \mathrm{t}, \mathrm{s}, \mathrm{tx}$ & $12^{1}$ & $20^{2}(8)$ & 1 & $\mathrm{c}, \mathrm{t}, \mathrm{s}, \mathrm{tx}$ & $6^{3} \quad(5)$ & $16^{4}(5)$ \\
\hline 2 & $\mathrm{t}, \mathrm{s}, \mathrm{ntx}$ & $37^{1}(12)$ & $6^{2}(4)$ & 2 & $\mathrm{t}, \mathrm{s}, \mathrm{c}, \mathrm{ntx}$ & $27^{3}(10)$ & $10^{4}(5)$ \\
\hline 3 & $\mathrm{~s}, \mathrm{ntx}$ & $1^{1} \quad(1)$ & $1^{2}(1)$ & 3 & $\mathrm{~s}, \mathrm{c}, \mathrm{ntx}$ & $4^{3} \quad(3)$ & 0 (5) \\
\hline 4 & $c, n t x$ & $3^{1} \quad(3)$ & $0^{2}$ & 4 & $\mathrm{c}, \mathrm{s}, \mathrm{ntx}$ & $2^{3} \quad(2)$ & 0 (5) \\
\hline
\end{tabular}

Numbers in parentheses indicate how many birds contributed to each total. The cues are represented as $c=c o l o u r ;$ $\mathrm{t}=$ taste; $\mathrm{s}=$ smell; $\mathrm{tx}=$ toxicity; $\mathrm{ntx}=$ non-toxicity. Chi-squared values for each pair-wise comparison are indicated by superscripts: ${ }^{1} 14 \cdot 98, d f=1, P<0 \cdot 001 ;{ }^{2} 8 \cdot 18, d f=1, P<0 \cdot 01 ;{ }^{3} 14 \cdot 85, d f=1, P<0 \cdot 001 ;{ }^{4} 1 \cdot 50, d f=1$, Ns.

Table III. The numbers of eaten and rejected beetles in each session

\begin{tabular}{|c|c|c|c|c|c|c|c|}
\hline \multicolumn{4}{|c|}{ Session 1} & \multicolumn{4}{|c|}{ Session 2} \\
\hline Group & Cue & Eat & Reject & Group & Cue & Eat & Reject \\
\hline 1 & $\mathrm{c}, \mathrm{t}, \mathrm{s}, \mathrm{tx}$ & $21(10)$ & 144 & 1 & $\mathrm{c}, \mathrm{t}, \mathrm{s}, \mathrm{tx}$ & $10(6)$ & 155 \\
\hline 2 & $\mathrm{t}, \mathrm{s}, \mathrm{ntx}$ & $148(15)$ & 17 & 2 & $\mathrm{t}, \mathrm{s}, \mathrm{c}, \mathrm{ntx}$ & 63 (14) & 102 \\
\hline 3 & $\mathrm{~s}, \mathrm{ntx}$ & $157(15)$ & 8 & 3 & $\mathrm{~s}, \mathrm{c}, \mathrm{ntx}$ & $129(15)$ & 36 \\
\hline 4 & $\mathrm{c}, \mathrm{ntx}$ & 107 (14) & 58 & 4 & $\mathrm{c}, \mathrm{s}, \mathrm{ntx}$ & $143(15)$ & 22 \\
\hline
\end{tabular}

Numbers in parentheses indicate how many birds contributed to each total. The cues are represented as $\mathrm{c}=$ colour; $\mathrm{t}=$ taste; $\mathrm{s}=$ smell; $\mathrm{tx}=$ toxicity; $\mathrm{ntx}=$ non-toxicity. All pair-wise comparisons give very large chi-squared values $(P<0 \cdot 001)$ except session 1 group 2 versus group $3\left(\chi^{2}=3 \cdot 5, d f=1\right.$, Ns) and session 2 group 3 versus group $4\left(\chi^{2}=4 \cdot 1\right.$, $d f=1, P<0 \cdot 05)$.

\section{The Colour Pattern}

The treatment offering only the colour pattern (see Fig. 1d) caused an initially high level of rejection that declined steadily over the 11 trials. The trend was highly significant when tested with a Spearman rank correlation $\left(r_{\mathrm{S}}=-0.825\right.$, $N=11,11, P<0 \cdot 01)$.

\section{DISCUSSION}

This experiment demonstrates a clear difference in the degree to which the colour, taste and smell of the insect prey influenced the quail's responses. In line with other workers (Wilcoxen et al. 1971; Gillette et al. 1980), we found that colour was the most effective cue, and smell the least effective of those tested. The birds apparently failed to associate seven-spot ladybird smell with the effects of eating them. The taste, although unpleasant to humans (M. Rothschild, personal communication; P. M. Brakefield \& N. M. Marples, personal observation), did not appear to be more than a very mild deterrent on its own (Fig. 1b). The effect of colour alone was initially large, but transitory (Fig. 1d).

When paired with taste, the combination of cues (Fig. 1b) caused the birds to reject at a similar level to that when given the whole beetle (Fig. 1a) and prevented the swift extinction of the avoidance. As the taste treatment alone did not give such avoidance, the toxic properties of the reflex fluid cannot be responsible for this effect. The amounts used for these treatments were in any case very small.

Despite continued rejection, the combination of colour and taste did not cause the birds to maintain the very high initial level of avoidance. Mühlmann (1934) also concluded from his experiments offering distasteful red-painted mealworms to birds, that taste and the colour red are not enough to maintain rejection. Rejection was fully maintained in the treatments only where whole sevenspot ladybirds were offered, although even in these treatments, rejection never reached $100 \%$ (Fig. 1a). The birds sampled occasionally, and often att learned do not a but lear exposur: sional si getfulne been ex environ in prey mimics mon st mimics Marple priate.

The tected (Fig. 1 1991) replace bleedin in the despite Howey the se twice change The could ladybi for a beetles ladybi more that $\mathrm{t}$ attract smell when ing th The to $\mathrm{py}$ descri 1987; 1990) ing at their yet b pyraz birds beetle The these 
often attacked without eating, even after they had learned to avoid seven-spot ladybirds (naive birds do not avoid seven-spot ladybirds to this degree, but learn avoidance over their first three to six exposures; Marples 1990). Such continued occasional sampling, occurring too frequently for forgetfulness to provide a plausible explanation, has been explained as an adaptation to a changing environment, allowing the birds to detect changes in prey quality and the presence of Batesian mimics (Turner 1984; Speed 1990). Several common species have been proposed as Batesian mimics of seven-spot ladybirds (Brakefield 1985; Marples 1990), so such behaviour is not inappropriate.

The bled ladybirds were still sufficiently protected to maintain avoidance at its highest level (Fig. 1a). It has been shown (Holloway et al. 1991) that these beetles need over a week to replace their full quota of reflex blood after bleeding. It may be that enough toxin is retained in the beetle's body to maintain full avoidance despite inability to bleed in response to attack. However, as very few beetles were sampled in the second session (only three birds sampled twice or more), few birds will have detected the change in the ladybirds.

The results support the view that the birds could detect the smell associated with crushed ladybird, but they largely did not use it as a cue for avoidance. Although significantly fewer beetles in total were eaten in the presence of ladybird smell than without smell, they were eaten more quickly in nine out of 11 trials. This suggests that the smell of a seven-spot ladybird somehow attracted the birds. When colour was added to smell (Fig. Ic) avoidance was much lower than when colour was presented alone, again supporting the idea that smell was an attractant.

The smell of seven-spot ladybirds is partly due to pyrazines (Moore et al. 1990), chemicals described as 'alerting odours' (Guilford et al. 1987; Rothschild \& Moore 1987; Moore et al. 1990). They enhance at least the positional learning ability of animals (Kaye et al. 1989), although their effects on colour pattern learning have not yet been tested. It is possible that the presence of pyrazines from the crushed ladybird caused the birds to learn to accept the perfectly edible control beetle more readily than when they were absent. The influence of smell may be underestimated in these experiments since the crushed ladybird may have produced other masking smells as well as those used as warning odours. In addition, the perforated bottom of the petri dish may have formed a partial barrier, preventing the full odour reaching the quail.

The multi-component chemical defence of the seven-spot ladybird gives birds the opportunity to reject the beetle at various stages. In those cases when visual cues are enough, the ladybird is certain to survive, but once pecked there is a danger of mortal injury even for those not eaten. The birds usually rejected the beetle once reflex blood was tasted (a chew), but a gentler attack which did not cause reflex bleeding (a peck) often led to re-attack. Victims of pecks and chews were not kept separately, so it is not known whether seven-spot ladybirds ever die after pecks, but more chews were recorded than fatalities, so chews are certainly not always fatal. Of the beetles attacked by our experienced quail, $46 \cdot 7 \%$ of unbled and $37 \%$ of bled ladybirds survived. Such high survival rates support the idea that individual selection may play a role in the maintenance of aposematism in this species, although the relative influences of synergistic (Guilford 1985; Guilford \& Cuthill 1991) and individual selection (Sillén-Tullberg 1985) cannot be separated in our data (cf. Wiklund \& Jarvi 1982 using naive birds).

In conclusion, these results demonstrate that colour pattern is the most important cue used by quail, with taste used as a secondary cue. There is a synergistic effect such that together, colour, taste and smell cause an initial rejection level only just below that caused by the whole ladybird, but this high avoidance is not sustained unless backed up by the toxicity of the whole beetle.

\section{ACKNOWLEDGMENTS}

We thank all those who helped in collecting and feeding the ladybirds, especially Mike Majerus and Peter de Jong. We are also grateful to Els Schlatmann and her colleagues for cultivating bean plants as aphid food. We also thank Helene de Vos for help with the alkaloid analysis, and Graham Holloway for helping with reflex bleeding techniques, and for his useful comments on the manuscript. Finally, we thank the referees and European Editor for many helpful and constructive comments. 


\section{REFERENCES}

Brakefield, P. M. 1985. Polymorphic Mullerian mimicry and interactions with thermal melanism in ladybirds and a soldier beetle: a hypothesis. Biol. J. Linn. Soc., 26, 243-267.

Brower, L. P. 1984. Chemical defence in butterflies. In: The Biology of Butterflies (Ed. by R. Vane-Wright \& P. Ackery), pp. 109-134. London: Academic Press.

Clark, L. \& Mason, J. 1987. Olfactory discrimination of plant volatiles by the European starling. Anim. Behav., 35, 227-235.

Cuenot, L. 1896. Sur la saignee reflexe et les moyens de defense de quelques insectes. Archs Zool. exp. gén., 4, 655-680.

Gillette, K., Martin, G. M. \& Bellingham, W. P. 1980. Differential use of food and water cues in the formation of conditioned aversions by domestic chicks (Gallus gallus). Am. Psychol. Ass., 6, 99-111.

Guilford, T. 1985. Is kin selection involved in the evolution of warning coloration? Oikos, 45, 31-36. -

Guilford, T. \& Cuthill, I. 1991. The evolution of aposematism in marine gastropods. Evolution, 45, 449 451.

Guilford, T., Nicol, C., Rothschild, M. \& Moore, B. P. 1987. The biological roles of pyrazines: evidence for a warning odour function. Biol. J. Linn. Soc., 31, 113-128.

Hodek, I. 1973. Biology of Coccinellidae. Prague: Academia.

Holloway, G. J., de Jong, P. W., Brakefield, P. M. \& de Vos, H. 1991. Chemical defence in ladybird beetles (Coccinellidae). I. Distribution of coccinelline and individual variation in defence in 7-spot ladybirds (Coccinella septempunctata). Chemoecology, 2, 7-14.

Kay, D., Rothschild, M. \& Aplin, R. 1969. Particles present in the haemolymph and defensive secretions of insects. J. Cell Sci., 4, 369-379.

Kaye, H., Mackintosh, N. J., Rothschild, M. \& Moore, B. P. 1989. Odour of pyrazine potentiates an association between environmental cues and unpalatable taste. Anim. Behav., 37, 563-568.

Majerus, M. E. N. \& Kearns, P. 1989. Ladybirds. Slough: Richmond Publishing.

Marples, N. M. 1990. Influences of predation on ladybird colour patterns. Ph.D. thesis, University of Wales, College of Cardiff.
Marples N. M. \& Brakefield P. M. In press. Genetic variation for the rate of recruitment of novel insect prey into the diet of a bird. Biol. J. Linn. Soc.

Marples, N. M., Brakefield, P. M. \& Cowie, R. J. 1989. Differences between the 7-spot and 2-spot ladybird beetles (Coccinellidae) in their toxic effects on a bird predator. Ecol. Entomol., 14, 7984.

Moore, B. P., Brown, W. V. \& Rothschild, M. 1990. Methylalkylpyrazines in aposematic insects, their hostplants and mimics. Chemoecology, 1, 43-51.

Mühlmann, H. 1934. Im modellversuch künstlich erzeugte mimikry und ihre bedeutung für den 'nachahmer'. Z. Morph. Ökol., 28, 259-296.

Pasteels, J. M., Deroe, C., Tursch, B., Breakman, J. C., Daloze, D. \& Hootele, C. 1973. Distribution et activités des alcaloïdes defensifs des Coccinellidae. J. Insect Physiol., 19, 1771-1784.

Pasteur, G. 1982. A classificatory review of mimicry systems. A. Rev. Ecol. Syst., 13, 169-199.

Rothschild, M. \& Moore, B. 1987. Pyrazines as alerting signals in toxic plants and insects. In: Insects-Plants (Ed. by V. Labeyrie, G. Fabres \& D. Lachaise), pp. 97-101. Dordrecht: Dr W. Junk.

Sillén-Tullberg, B. 1985. Higher survival of an aposematic than of a cryptic form of a distasteful bug. Oecologia (Berl.), 67, 411-415.

Speed, M. P. 1990. Mimicry and the psychology of predation. Ph.D. thesis, University of Leeds.

Tucker, D. 1965. Electrophysiological evidence for olfactory function in birds. Nature, Lond., 207, 34-36.

Turner, J. R. 1984. Mimicry: the palatability spectrum and its consequences. In: The Biology of Butterflies (Ed. by R. I. Vane-Wright \& P. R. Ackery), pp. 141161. New York: Academic Press.

Wiklund, C. \& Jarvi, T. 1982. Survival of distasteful insects after being attacked by naive birds: a reappraisal of the theory of aposematic coloration evolving through individual selection. Evolution, 36, 998-1002.

Wilcoxen, H. C., Dragoin, W. B. \& Kral, P. A. 1971. Illness-induced aversions in rat and quail: relative salience of visual and gustatory cues. Science, 171, 826-828. 